\title{
Nodular scleritis with strongly positive serum rheumatoid factor: forme frusté rheumatoid arthritis sans arthritis
}

\author{
Mohd Sabir, ${ }^{1}$ Brijesh Takkar, ${ }^{1}$ Rajnish Joshi, ${ }^{2}$ Anubha Rathi ${ }^{3}$
}

${ }^{1}$ Department of Ophthalmology, All India Institute of Medical Sciences, Bhopal, India ${ }^{2}$ General Medicine, All India Institute of Medical Sciences, Bhopal, India

${ }^{3}$ Dr Rajendra Prasad Centre for Ophthalmic Sciences, All India Institute of Medical Sciences, New Delhi, India

\section{Correspondence to}

Dr Anubha Rathi,

ana.aiims@gmail.com

Accepted 29 December 2018

\section{DESCRIPTION}

A 56-year-old woman presented with a solitary painful nodule right eye for 3 days along with intense photophobia. There was a documented history of two previous episodes of scleritis. Visual acuity was 20/20 in both eyes. Ocular examination revealed a severely tender raised erythematous lesion over the lateral aspect of the sclera of right eye (figure 1A). The lesion did not blanch on instillation of topical phenylephrine, ruling out episcleritis. Rest of the ocular examination of either eye was within normal limits. Optical coherence tomography of the lesion confirmed its nodularity (figure 2). She was diagnosed to have nodular scleritis and referred to a physician for systemic workup which showed no significant finding suggestive of an underlying chronic present or past illness.

Blood investigations were ordered which revealed a highly raised erythrocyte sedimentation rate of $170 \mathrm{~mm} /$ hour and a strongly positive serum rheumatoid factor (RF) reported as $>120 \mathrm{IU} / \mathrm{mL}$. Other possible causes of scleritis such as chronic infections and granulomatosis with polyangiitis were ruled out with appropriate investigations. ${ }^{1}$ The patient was started on sustained release oral indomethacin $75 \mathrm{mg}$ once a day, topical artificial tears and topical steroids, and oral methotrexate $7.5 \mathrm{mg}$ once a week (due to recurrent ocular episodes) with the working diagnosis of a possible rheumatoid arthritis (RA) in view of very high RF. The patient did not have any typical bilaterally symmetrical inflammatory polyarthritis that is usually seen in RA. The ocular lesion started resolving within 3-4 days of initiation of treatment and completely resolved by the seventh day of follow-up (figure 1B). While all drugs were continued for another week, oral methotrexate was continued in gradually escalating doses till a peak dose of $15 \mathrm{mg}$ once a week while monitoring for

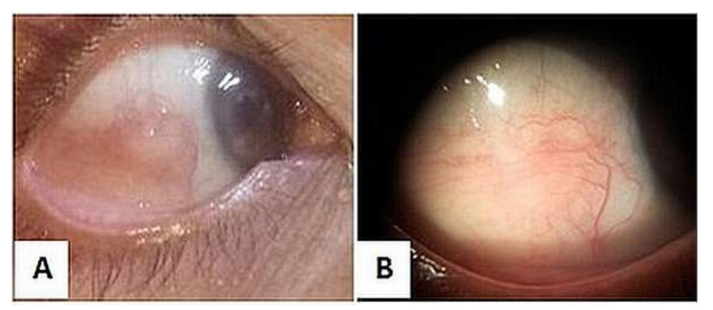

Figure 1 (A) Pretreatment clinical photograph showing a nodular scleritis of the right eye. (B) Posttreatment clinical photograph of right eye at seventh day demonstrating resolution of scleritis.

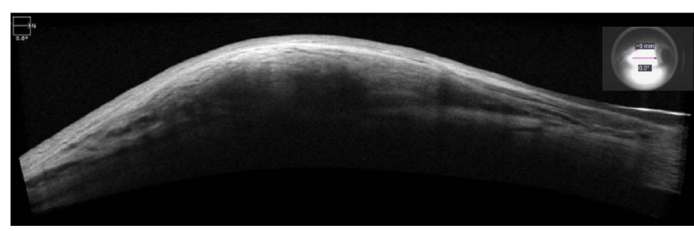

Figure 2 Optical coherence tomography depicting the nodule that appears to be arising from the sclera, though internal characters of the nodule cannot be seen due to optical shadowing.

toxicity. The patient remained asymptomatic till at least 3 months of follow-up.

Ocular manifestations of RA include dry eye (28\%), less commonly episcleritis (3\%) and rarely scleritis. The reported incidence of scleritis as an ocular manifestation of RA ranges from $0.7 \%$ to $6.3 \%$, although as many as one third of all patients presenting to an ophthalmologist with scleritis may have associated RA. However, almost always, ocular features follow the diagnosis of RA and don't usually precede it. ${ }^{2}$ Our patient did not satisfy the American College of Rheumatology/European League Against Rheumatism Classification criteria described for evaluating the possibility of RA. ${ }^{3}$ This is chiefly because of no sign of arthritis despite extensive examination and workup. Since the specificity of a positive RF is nearly $90 \%$ for a rheumatic disease and its titres were found to be exceedingly high, we diagnosed this case as probable RA. Keeping the possibility of a full-blown RA or any other rheumatic disease manifesting later, the patient was advised regular follow-up and careful observation.

\section{Learning points}

- Scleritis can have an underlying chronic disease process and all cases should be thoroughly investigated systemically.

- As scleritis may rarely be an initial manifestation of diseases like rheumatoid arthritis, a continuous surveillance for such disorders in the setting of repeated episodes is advisable.

- The current nomenclature/classification systems may consider including 'possible' disease or 'probable' disease as categories for describing such forme fruste manifestations while also setting guidelines for their follow-up. 
Contributors MS, BT and RJ worked up, managed and diagnosed the patient. BT performed imaging. All authors wrote the manuscript, AR critically revised it. BT is the over all guarantor.

Funding The authors have not declared a specific grant for this research from any funding agency in the public, commercial or not-for-profit sectors.

Competing interests None declared.

Patient consent Obtained.

Provenance and peer review Not commissioned; externally peer reviewed.

\section{REFERENCES}

1 Takkar B, Khokhar S, Kumar U, et al. Necrotising scleritis, keratitis and uveitis in primary antiphospholipid syndrome. BMJ Case Rep 2018; 2018:bcr-2017-220647.

2 Vignesh AP, Srinivasan R. Ocular manifestations of rheumatoid arthritis and their correlation with anti-cyclic citrullinated peptide antibodies. Clin Ophthalmol 2015:9:393.

3 Aletaha D, Neogi T, Silman AJ, et al. 2010 Rheumatoid arthritis classification criteria: an American College of Rheumatology/European League Against Rheumatism collaborative initiative. Arthritis Rheum 2010;62:2569-81.

Copyright 2019 BMJ Publishing Group. All rights reserved. For permission to reuse any of this content visit

https://www.bmj.com/company/products-services/rights-and-licensing/permissions/

BMJ Case Report Fellows may re-use this article for personal use and teaching without any further permission.

Become a Fellow of BMJ Case Reports today and you can:

- Submit as many cases as you like

- Enjoy fast sympathetic peer review and rapid publication of accepted articles

- Access all the published articles

Re-use any of the published material for personal use and teaching without further permission

For information on Institutional Fellowships contact consortiasales@bmjgroup.com

Visit casereports.bmj.com for more articles like this and to become a Fellow 